JOURNAL OF ENGINEERING SCIENCES

ЖУРНАЛ ІНЖЕНЕРНИХ НАУК

ЖУРНАЛ ИНЖЕНЕРНЫХ НАУК

Web site: http://jes.sumdu.edu.ua

Volume 4, Issue 2 (2017)

UDC 669.71-034.7:539.2/.6:629.33:338.5

\title{
Modern materials for automotive industry
}

Hovorun T. P., Berladir K. V., Pererva V. I., Rudenko S. G., Martynov A. I.

Sumy State University, 2 Rymskogo-Korsakova St., 40007, Sumy, Ukraine

Article info:

Paper received:

The final version of the paper received:

Paper accepted online:
September 30, 2017

December 2, 2017

December 4, 2017
*Corresponding Author's Address:

kr.berladir@pmtkm.sumdu.edu.ua

\begin{abstract}
The car industry uses a tremendous number of materials to build cars, including iron, aluminum, steel, glass, rubber, petroleum products, copper, steel and others. These materials have evolved greatly over the decades, becoming more sophisticated, better built, and safer. They've changed as new automotive manufacturing technologies have emerged over the years, and they're used in increasingly innovative ways. This article is devoted to systematization information on the introduction and application of modern materials in the automotive industry.

Given both domestic and foreign sources of information, it follows that car manufacturers are constantly pushing to create the lightest cars possible to increase speed and power. Research and development into lightweight materials is essential for lowering their cost, increasing their ability to be recycled, enabling their integration into vehicles, and maximizing their fuel economy benefits. Light weighting without loss of strength and speed properties is the present, and the future, of the automotive manufacturing industry. It brings innovative materials to the frontline of design.
\end{abstract}

Keywords: steel, aluminum, aluminum alloys, aluminum matrix composites, polymer and composite materials, plastics, lightweight materials.

\section{Introduction}

Automotive is one of the largest consumers of construction materials in the world [1]. Increasing the durability and reliability of the work of the parts of cars is a relevant and important problem of materials science. The development of the automotive industry, increasing the requirements for the quality and safety of used materials requires the creation and application of new forms. At the same time, the growth of resource requirements forms competition between manufacturers of different materials stimulates progress in developing their new types and improving quality [2-4].

The automotive industry employs the latest innovative developments that emerge from the development of science and new technologies. Among the main vectors in the modern automotive industry are:

- creation of intelligent cars that can handle various difficult situations on the road without driver involvement;

- development of cars with alternative energy sources among them the most well-known and successful Tesla car line.
The performance of the cars is constantly improving, because the engines become more efficient, the body is more aerodynamic, the transmission is improved, the rolling resistance of tires is reduced.

When creating a car, it is very important to reduce its mass. This allows maintaining the basic characteristics of the car, using less powerful engines that consume less fuel and emit less harmful substances into the atmosphere. In addition, the inertia of the car decreases and for its acceleration or breaking it is necessary to spend less energy. Lowering the weight of the car also reduces the load on the suspension parts, which increases their lifespan [5].

Lowering the weight of the car is due to the need to use new, lighter but rather durable materials that are usually more expensive, at the same time cars, for objective reasons, are becoming more complex and, accordingly, more difficult. New light construction materials should be offset by weight, including new units, and active and passive safety systems, reduced toxicity, and continuous improvement in comfort levels [6]. Lightweight constructions are increasingly used in automotive, aerospace and construction sectors, because using the low density materials allows reducing the structural weight of products. That may result in substantial fuel savings and a lower 
carbon footprint in transportation and facilitates manipulation of details in the house construction applications [7].

Moreover, the low material density leads to conservation of natural resources, since less material is required for manufacturing consumer goods.

More than half of the total volume in the production of a modern car consists of cast iron and steel parts $(55 \%)$, about $11 \%$ - plastics, the third place - aluminium alloys ( $9 \%$ ); rubber and glass -7 and $3 \%$ respectively; the share of non-ferrous alloys (magnesium, titanium, copper and zinc) does not exceed $1 \%$; other materials (varnishes, paints, electric wires, facing materials, etc.) make $13.5 \%$ (Fig. 1).

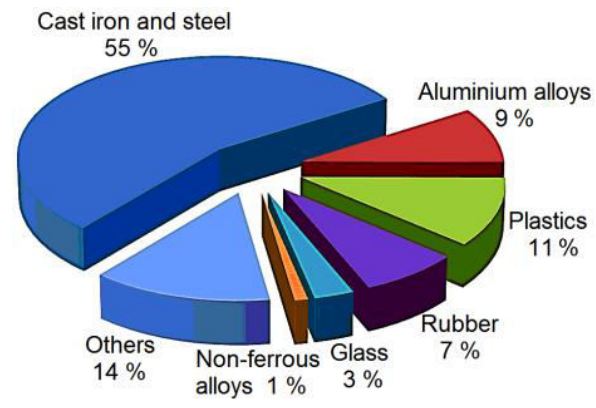

Figure 1 - Parts of various types of materials used for the manufacture of car parts

Traditionally, steel or various metal alloys are used to make all responsible parts of the car. Steel has high strength and reliability, but it is prone to corrosion, and the parts made of it, differ a fairly large mass [8].

Back in the 40th of the twentieth century, the first attempts were made to facilitate the design of the car through the use of parts made of synthetic fibers. Insufficiently worked out technology did not allow at that time to receive a material of high strength, therefore, from synthetic fibers originally manufactured only decorative panels of the car body.

Today, thanks to the use of the latest advances in science, polymer compounds demonstrate much greater hardness and strength than conventional steel. Due to the interweaving of synthetic fibers, a strong reinforcing frame is formed by which the load is evenly distributed over the entire surface of the part. In addition, carbon fiber parts weigh almost three times less than steel-like strengths [9].

In the manufacture of elements of modern engines, materials on the basis of composite with an aluminium matrix are widely used [10]. They represent an alloy of aluminium, in which are added fibers of silicon and carbon, previously passed through a special matrix made of titanium or aluminium. Such technology allows in several times to increase the strength of the material for tension.

The use of polymer materials can significantly reduce the cost of manufacturing automotive components [11].The details made of synthetic fibers by forming in the matrix, leave it fully ready for installation, without requiring additional processing and even colouring. From synthetic materials, it is not particularly difficult to make parts of a very complex form, which would be very difficult to do with sheet steel.

Polymer materials have virtually unlimited service life. They are not subject to corrosion; easily withstand the effects of significant loads and vibrations. The strength and stiffness of the car body elements made of synthetic fibers, can significantly improve the reliability and safety of the car while reducing its weight. The only obstacle to the widespread use of carbon fiber in automotive industry is the very high cost of its manufacture. A part made of synthetic fibers costs 30-40 times more expensive than a similar but made of steel. This leads to the fact that components from polymer materials are most often used in the manufacture of tuning cars of an individual assembly. However, over time, refinement of carbon fiber technologies will inevitably lead to a reduction in its value to the level of steel and light alloys.

In connection with the above, the main direction of development of the automotive industry should be a significant increase in the quality of products using scientific and technical advances and the development of new materials to be used in the automotive industry. And this continues the development of the scientific direction of applied material science in the automotive industry.

The purpose of this work is to systematize information on the introduction and application of modern materials in the automotive industry.

\section{Steel construction materials for the manufacture of car parts}

Despite the increasing use of new construction materials in the automotive industry, steel production continues to play a leading role in the production of steel.

On modern cars, most of the weight comes from steel. In 2007, for example, the average car contained $1090 \mathrm{~kg}$ of steel, and the average pickup truck or SUV used nearly $1360 \mathrm{~kg}$ [12].

The automobile industry is imposing very high demands on steel because, first of all, it must meet two diametrically opposite criteria. On the one hand, the requirement to reduce the mass of products involves the use of high-strength materials, on the other - the growth requirements for the production of technology involve the use of high-plastic materials [13].

Steel is the time-tested material. This material has been used in the manufacture of car bodies for a long time, thanks to its strength [13] (Fig. 2).

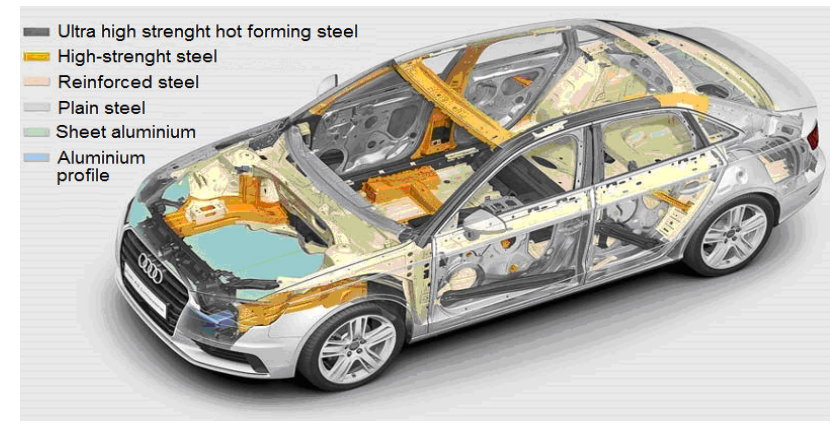

Figure 2 - Materials used for the manufacture of car bodies 
Requirements for materials for the manufacture of automobile bodies [14]:

- high strength;

- energy intensity (ability to absorb impact energy when collision);

- manufacturability(the possibility of manufacturing parts of a complex form with a minimum number of operations);

- minimum car body weight(the smaller the mass, the less the gas flow and the number of congenital emissions);

- corrosion resistance;

- maintainability.

Steel manufacturing has evolved greatly, so carmakers these days can make different types of steel for different areas of the vehicle that are rigid or that can crumple to absorb different impacts [15].

The main parts of the car body are made of steel, aluminium alloys, plastics and glass. Moreover, the advantage is given to low-carbon sheet steel in the thickness of

Table 1 - Types of sheet steel for car bodies

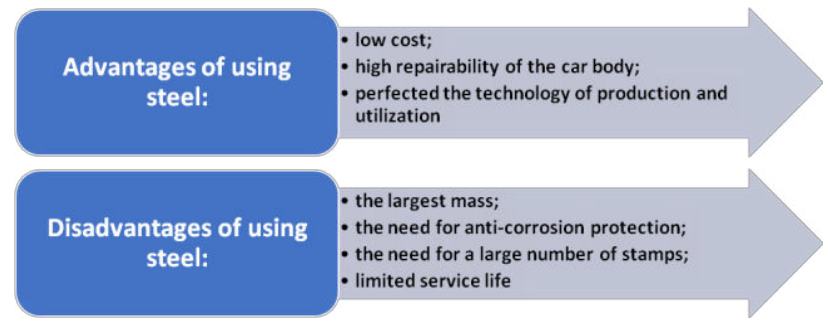

Figure 3 - Advantages and disadvantages of using steel materials for automotive industry

(0.65-2) mm. Thanks to the latter, it managed to reduce the overall weight of the car and increase the rigidity of the body.

The use of steel materials for cars has its advantages and disadvantages [13] (Fig. 3).Most car bodies, due to many reasons, are made of sheet steel. The most important of these reasons are: high strength, deformability (possibility of extraction), welding, coloring, sufficient service life with proper anticorrosion treatment, satisfactory cost (Table 1).

\begin{tabular}{|c|c|c|c|}
\hline Steel & $\begin{array}{c}\text { Type } \\
\text { of steel }\end{array}$ & Properties & Appoinment \\
\hline $\begin{array}{c}\text { Thin sheet, } \\
\text { cold-rolled } \\
\text { killed }\end{array}$ & RRST 1405 & $\begin{array}{c}\text { the limit of strength 270-350 MPa, } \\
\text { relative elongation is more than 36\%, } \\
\text { thickness 0.6-0.9 mm }\end{array}$ & $\begin{array}{c}\text { specific external panels (roof, hood, door, } \\
\text { sidewalls, etc.) }\end{array}$ \\
\hline $\begin{array}{c}\text { Thin sheet, } \\
\text { boiling steel }\end{array}$ & $\begin{array}{c}\text { UST 1203, } \\
\text { UST 1303 }\end{array}$ & $\begin{array}{c}\text { the limit of strength } 270-410 \mathrm{MPa}, \\
\text { relative elongation } 28-32 \%, \\
\text { thickness 0.6-0.9 mm }\end{array}$ & $\begin{array}{c}\text { painted external panels and floor parts } \\
\text { (inner frame, amplifiers, floor panels, } \\
\text { cross bars) }\end{array}$ \\
\hline $\begin{array}{c}\text { Hot-rolled } \\
\text { steel tape }\end{array}$ & ST 4 & $\begin{array}{c}\text { the limit of strength } 280-380 \mathrm{MPa}, \\
\text { relative elongation is more than 38\%, } \\
\text { thickness 1.5-2.5 mm }\end{array}$ & $\begin{array}{c}\text { for parts located beneath the car body } \\
\text { (amplifiers, supports, flanges, etc.), } \\
\text { especially large thickness }\end{array}$ \\
\hline
\end{tabular}

The design and manufacturing technology of the parts should be guided by the maximum width of the supplied steel sheet (currently $2000 \mathrm{~mm}$ ). For parts working in a corrosive-aggressive environment, it is necessary to use galvanized sheet steel, given that in the manufacture of parts, such steel does not allow large decompositions (bend, a small exhaust).In special cases aluminum sheet steel can be used. Both surfaces of steel sheets can be specially treated. Material scientists are also working towards the development and application of ultra-highstrength alloys of the new generation [13] (Fig. 4).

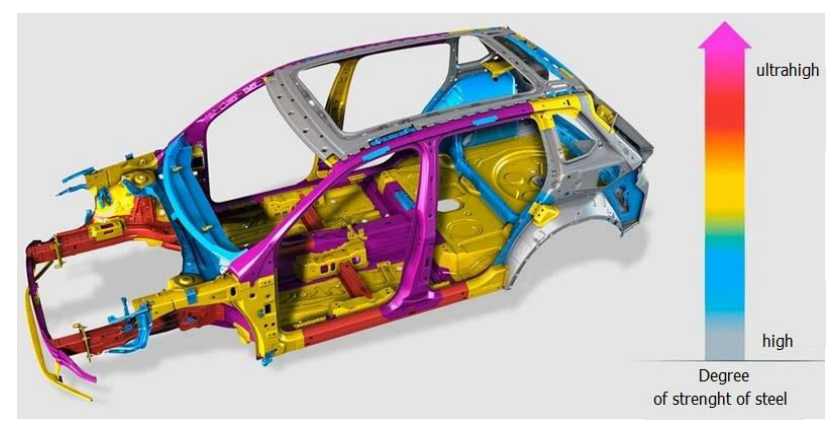

Figure 4 - Possibilities of application of ultra-high-strength alloys of new generation for details of the car

An example of using high-strength and especially high-strength steels in a car can serve as a model Audi Q5. The share of standard soft steels in the car body of this crossover is $31 \%$ (made of especially stubborn components and external components that absorb energy when struck), high-strength - more than $44 \%$ (almost the entire power frame protecting passengers), especially high-strength - almost $25 \%$ (of which $9.1 \%$ are ultrahigh strength steel of the new generation, which are used in the most responsible areas) [4].

Among the steels used in automobile construction, it is possible to note [4]:

1. Highly-plastic IF-steel, the structure of which is stabilized with micro-nutrients of titanium and/or niobium, and contains an extremely low carbon $(\leq 0.005 \%)$, which, together with nitrogen, is completely bound to carbides, nitrides and carbonitrides.

2. Steels, which are strengthened during the drying of paint and varnish coating (BH-steel). The advantage of 
BH-steels is the strengthening, which is achieved in a single technological flow during the drying of the paint and varnish coating of the car body.

3. Dual Phase (DP) steels with ferrite-martensitic (or ferrite-bainite) structure have high properties. «Soft» ferrite (up to $80 \%$ ) provides high plastic properties of DP-steels in its original state.

4. Transformation Induced Plasticity (TRIP) steels, the microstructure of which is a ferrite matrix with dispersion-distributed inclusions of a strong martensitic and/or bainitic component.

5. Complex Phase (CP) steels have a highly dispersed ferrite structure with a large volume fraction of solid phases (structural components).

6. Sheet steel containing $0.07 \% \quad \mathrm{C}, \quad 0.6 \% \quad \mathrm{Si}$, $2.4 \% \mathrm{Mn}$, has such typical properties of properties: $\sigma_{T}=710 \mathrm{~N} / \mathrm{mm}^{2}, \sigma_{B}=1010 \mathrm{~N} / \mathrm{mm}^{2}, \delta_{5}=14 \%$, $\delta_{p}=8 \%$.

7. Martensitic (Mart) steels provide the value of the temporary resistance to $1500 \mathrm{~N} / \mathrm{mm}^{2}$. These were subjected to quenching with subsequent tempering to increase the plasticity and ensure high molding at very high deformation values.High-strength sheet steel is used mainly for rigidity elements. Details from such steels are made flexible in the stamps or roller machines, but such become prone to cracking and elastic return.In recent years, transition to more high-tech processes hot sheet punching with hardening in the die.

8. Each year, the use of high-strength steels of the new generation such as AHSS (advanced high-strength steels) and UHSS (ultra high-strength steels) with the limit of fluidity of 400 to $1200 \mathrm{~N} / \mathrm{mm}^{2}$ increases. It should be borne in mind that their application requires not only significant changes in methods design details, but also stamping technology, the development of new technologies for the manufacture of parts and units (hydro-forming, profiling, laser welding of the body, etc.) [15]. Foreign experience shows that the steel of these types is expedient to use on automakers manufacturing components that affect the passive safety of the car (safety bars, spares, elements of the bumper system, etc.).

9. High-strength austenitic steels $\left(\sigma_{T} \geq 600 \mathrm{~N} / \mathrm{mm}^{2}\right)$ (Twinning Induced Plasticity - TWIP steels), which have very high plastic properties (full elongation of more than $80 \%$ ), are actively developed. The unique properties of these high-manganese (up to $30 \% \mathrm{Mn}$ ) steels containing up to $9 \%$ aluminum are provided by double-crystalline lattice. Low energy of packing defects combined with reinforcing deformation martensitic transformations allows to effectively strengthen these steels when hydro-pressing.

10. High-strength and super-plastic steels of a new generation for lightweight structures (TRIPLEX-steels) on the basis of a four-component system Fe-Mn-Al-C with an aluminum content of up to $12 \%$ are characterized by a lower specific mass (up to $14 \%$ ), high limit of fluidity (800-1 $000 \mathrm{~N} / \mathrm{mm}^{2}$ ) increased relative elongation (up to $70 \%$ ) and excellent ability to deep extract. The structure of steel consists of austenitic ma- trix, volumetric ferrite particles and nano-dispersed particles of carbides. This is achieved by thermal treatment with a controlled and even distribution of $k$-carbides, which results in a precision uniform displacement of the crystal lattice. This leads to extremely high formability. This mechanism is designated as SIP-effect (shear band induced plasticity).

11. Nano-structured hot-rolled steel NANOHITEN (development by the company JFE Steel) with high limit of fluidity $\left(780 \mathrm{~N} / \mathrm{mm}^{2}\right)$ is based on ferrite structure, strengthened with dispersed particles. Such a microstructure provides a high value of relative elongation (up to $25 \%$ ). Since NANOHITEN steel does not contain silicon, it is well exposed to hot zinc and is already used in body structures and safety components, as well as for levers, brackets and chassis parts.

Perspectives of the development of steel materials for automotive industry are shown in Figure 5.

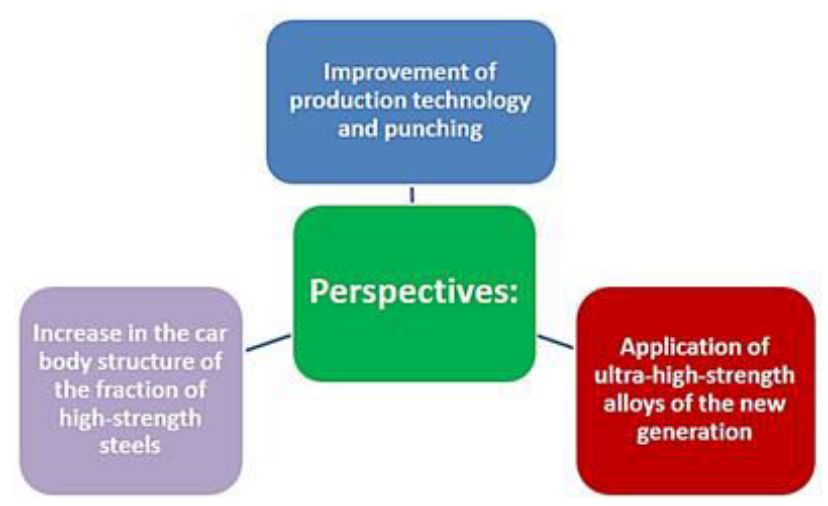

Figure 5 - Perspectives for the development of steel materials for automotive industry

\section{Results and discussion}

\subsection{Aluminum alloys and composites with an aluminum matrix for automotive industry in order to reduce the weight of cars}

Aluminum alloys for the manufacture of car bodies began to be used relatively recently [17]. But this metal has already gained popularity among automakers, because it is lightweight and virtually non-corrosive. With the use of aluminum alloys are made both body and some parts of the suspension and engine. The disadvantage of using aluminum is a laborious process of welding components and high conductivity vibration and noise. To reduce vibration and noise, manufacturers use silent insulation, which ultimately affects the price of the car [13] (Fig. 6).

Aluminum car bodies have already reached the level of mass production, although only on expensive models. Many parts of the chassis have been mastered from aluminum instead of steel, as well as lighter components. But the struggle with the weight of the car continues and goes to a new level in connection with the rigor of demands for efficiency and environmental friendliness. 


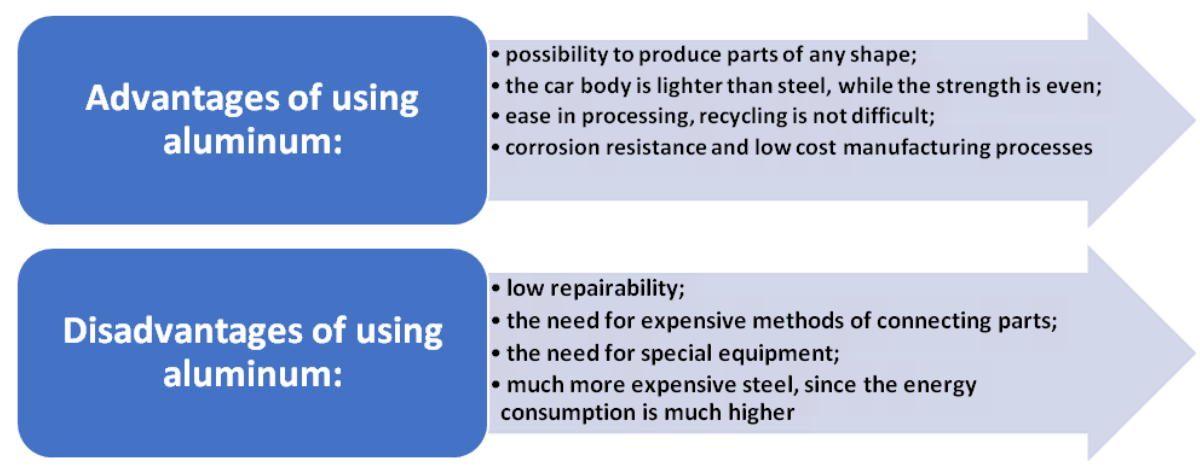

Figure 6 - Advantages and disadvantages of using aluminum for automotive industry

Aluminium in this struggle, of course, is still a leading place, since there are also more attractive materials with high mechanical properties, but even more light. Mastering them in mass production are leading automotive firms and component manufacturers [4].

Audi Company uses new aluminum in its production, which affects the price. But not all manufacturers can completely switch to aluminum car bodies, so they have to combine aluminum with steel to make the car cheaper. Concern BMW manufactures some series of cars with this technology.For example, in the fifth series the front part of the car body is made entirely of aluminum alloy and welded with a steel frame.

The use of aluminum and its alloys for the manufacture of car bodies is practiced by automobile manufacturerssuch as Rover, Jaguar, Audi and BMW. Thanks to aluminum, the car gets much easier; this affects the increase in speed, reducing $\mathrm{CO}_{2}$ and fuel consumption.This material is almost not subject to corrosion. Due to the excellent ductility metal effectively quenches impacts in case of an accident. But this same plasticity leads to the deformation of aluminum body parts, even when there are not very serious blows.

Aluminum alloys are now used not only for the body of the car, but also for a number of parts of the steering knobs and suspensions. The physical and mechanical properties of this metal impose special requirements for the preparation and repair of aluminum parts.

Low density of aluminum alloys, high machinability, ductility and fatigue strength; up to $30 \%$ less, in comparison with cast iron, the coefficient of transmission from gas, as well as high thermal conductivity at the level 125 $146 \mathrm{~W} / \mathrm{m} \cdot \mathrm{K}$ made them the main piston materials of the present [18].

\subsection{Aluminum alloys for automotive industry}

The problem of improving the quality of aluminum alloys is relevant for all developed countries [19, 20].

The main tasks for the production of aluminum alloys used for automotive industry include the development of materials with the highest hardness, durability, corrosion resistance, plasticity and other physical and mechanical properties. To do this, various methods and techniques for improving these characteristics are used.

One of the most important tasks is the purposeful management of the molded structure and properties of silumines in the bulk crystallization of castings in conventional non-stationary processes of traditional casting.

The production and casting of aluminum alloys are widely used modification. Additives are introduced as a ligature in the charge or directly into the melt. Among the modifiers of the first kind of aluminum alloys are titanium and vanadium, which form refractory inter-metallic $\mathrm{TiAl}_{3}$ and $\mathrm{VAl}_{6}$, and ultrafine particles of oxides, carbides, borides and other nonmetallic inclusions. Modifiers second kind are surfactants which positively affect the structure of aluminum alloys, most of which are elements of group ( $\mathrm{Li}, \mathrm{Na}, \mathrm{K}, \mathrm{Rb}, \mathrm{Cs}$ ), and sulfur and phosphorus. At the same time, numerous studies have shown the high efficiency of complex modifiers [18].

Effective grinding of grain of aluminum alloys is possible due to the adding of fine-dispersed aluminumtitanium-boron (AlTiB) and aluminum-titanium-carbon (AlTiC) crystals in the melt of various compositions that serve as crystallization centers. Adding this ligature results in improved mechanical properties and reduced gas porosity. The ligature is applicable to all aluminum alloys (pure aluminum, deformed alloys, and cast silumines.

The authors [21] with the aim of improving the structure, mechanical and service properties, lower porosity, based on laboratory and pilot studies as a baseline for hypo-eutectoid silumins proposed a modifier containing elements which act as modifiers and second kind. The modifier included sulfur, sodium carbonate, ultrafine silicon carbide and electrolytic titanium. The results of research on the basis of the modifying complex allowed developing a number of highly effective refiningmodifying complexes for the processing of aluminum alloys obtained from low-grade raw materials [22-24].

Actual problem is the cheapening of raw materials of aluminum alloys by their recycling. The authors [18] have shown that the increase in the quality of silumins derived from $100 \%$ of secondary raw materials to the level of primary, possibly due to the use of experimental refining-modifying complexes. The developed complexes have a low cost, do not complicate the technology of obtaining alloys, reduce the amount of harmful emissions into the environment and improve the sanitary standards in foundries, reduce the need for universal refiningmodifying preparations in 10-15 times.

Due to the use of proposed modifiers, the possibility of using silumins for more stringent conditions of forced 
work in knots and mechanisms of machines, especially for products of tribo-technical purposes, expands. Cast billet of silumines having sufficient level of plasticity (not less than 4-6\%), can be subjected to pressure treatment to enhance the properties and to ensure the accuracy of the shape of the product [25].

\subsection{Aluminum matrix composites for the automotive industry}

Aluminum matrix composites (AMCs) refer to the class of light weight high performance aluminum centric material systems. The reinforcement in AMCs could be in the form of continuous/discontinuous fibers, whisker or particulates, in volume fractions ranging from a few percent to $70 \%$. Properties of AMCs can be tailored to the demands of different industrial applications by suitable combinations of matrix, reinforcement and processing route $[17,26]$

ThemajoradvantagesofAMCscomparedtounreinforcedmaterialsareasfollows: greater strength, improved stiffness, reduced density (weight), improved high temperature properties, controlled thermal expansion coefficient, thermal/heat management, enhanced and tailored electrical performance, improved abrasion and wear resistance, control of mass (especially, in reciprocating applications) and improved damping capabilities [17].

AMCs can be classified into four types depending on the type of reinforcement [26] (Fig. 7).

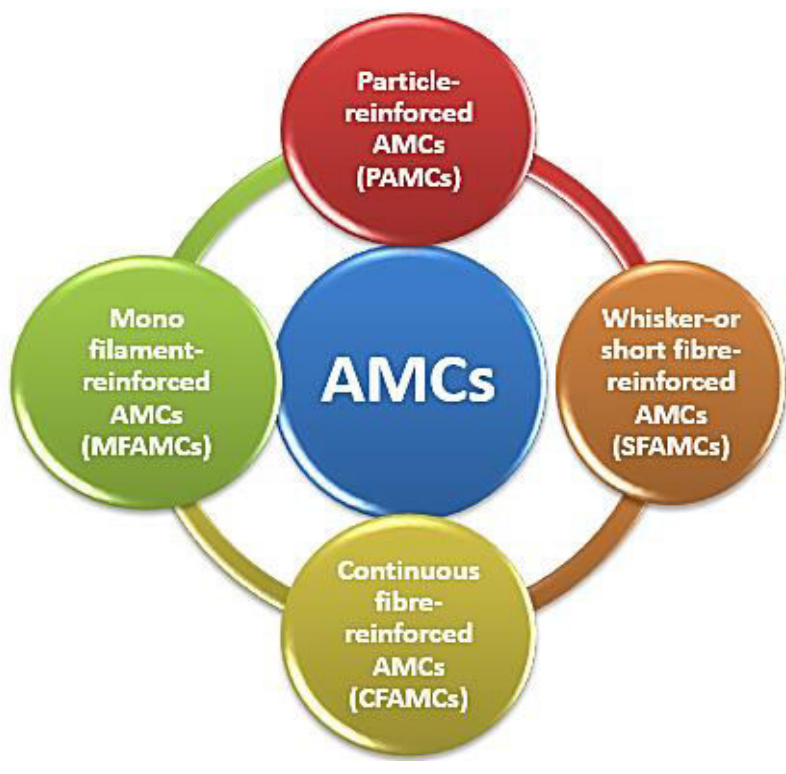

Figure 7 - Types of AMCs

Particulate Reinforced Aluminum Matrix Composites (PAMCs) are one of the key research and development areas of metal matrix composites. The development prospect is very broad and will lead the revolution of advanced materials through large-scale production and application [27].

These composites generally contain equated ceramic reinforcements with an aspect ratio less than about 5 . Ceramic reinforcements are generally oxides or carbides or borides ( $\mathrm{Al} 2 \mathrm{O} 3$ or $\mathrm{SiC}$ or $\mathrm{TiB} 2)$ and present in volume fraction less than $30 \%$ when used for structural and wear resistance applications [28-30].

In general, PAMCs are manufactured either by solid state (PM processing) or liquid state (stir casting, infiltration and in-situ) processes.

PAMCs are less expensive compared to CFAMCs. Mechanical properties of PAMCs are inferior compared to whisker/short fiber/continuous fiber reinforced AMCs but far superior compared to unreinforced aluminium alloys. These composites are isotropic in nature andcan be subjected to a variety of secondary forming operations including extrusion, rolling and forging. Figure 8 a shows the microstructure of cast aluminium matrix composite having high volume fraction (40 vol. \%) SiC particle reinforcements [17].

Whisker or short fiber-reinforced AMCs (SFAMCs) contain reinforcements with an aspect ratio of greater than 5, but are not continuous. Short alumina fiber reinforced aluminium matrix composites is one of the first and most popular AMCs to be developed and used in pistons. These were produced by squeeze infiltration process. Figure $8 \mathrm{~b}$ shows the microstructure of short fiber reinforced AMCs. Whisker reinforced composites are produced by either by PM processing or by infiltration route [17]. Mechanical properties of whisker reinforced composites are superior compared to particle or
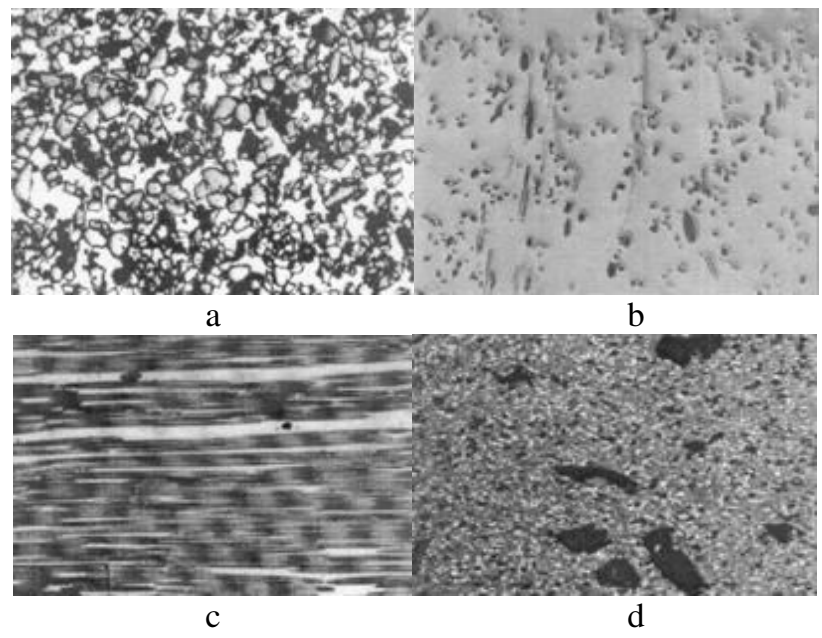

Figure 8 - Microstructures of aluminum matrix composite having high volume fraction of $\mathrm{SiC}$ particle reinforcement (40\% vol.) (a), short fiber-reinforced aluminum matrix composite (b); continuous fiber-reinforced aluminum matrix composite (c); hybrid composite containing $10 \% \mathrm{SiC}$ and $4 \%$ graphite particles (d)

short fiber reinforced composites. However, in the recent years usage of whiskers as reinforcements in AMCs is fading due to perceived health hazards and, hence of late commercial exploitation of whisker reinforced composites has been very limited. Short fiber reinforced AMCs display characteristics in between that of continuous fiber and particle reinforced AMCs[31].

Continuous fiber-reinforced aluminum matrix composites (CFAMCs). Here, the reinforcements are in the form 
of continuous fibers (of alumina, $\mathrm{SiC}$ or carbon) with a diameter less than $20 \mathrm{~m}$. The fibers can either be parallel or pre woven, braided prior to the production of the composite. AMCs having fiber volume fraction upto $40 \%$ are produced by squeeze infiltration technique. More recently $3 \mathrm{MTm}$ corporation has developed $60 \%$ vol. alumina fiber (continuous fiber) reinforced composite having a tensile strength and elastic stiffness of $1500 \mathrm{MPa}$ and $240 \mathrm{GPa}$ respectively. These composites are produced by pressure infiltration route. Figure $8 \mathrm{c}$ shows the microstructure of continuous fiber (alumina) reinforced AMCs [17].

Mono filament reinforced aluminium matrix composites (MFAMCs). Monofilaments are large diameter (from 100 to $150 \mathrm{~m}$ ) fibers, usually produced by chemical vapour deposition (CVD) of either SiC or B into a core of carbon fiber or $W$ wire. Bending flexibility of monofilaments is low compared to multifilament. Monofilament reinforced aluminium matrix composites are produced by diffusion bonding techniques, and is limited to super plastic forming aluminium alloy matrices. In CFAMCs and MFAMCs, the reinforcement is the principal loadbearing constituent, and role of the aluminium matrix is to bond the reinforcement and transfer and distribute load. These composites exhibit directionality. Low strength in the direction perpendicular tothe fiber orientation is characteristic of CFAMCs and MFAMCs. In particle and whisker reinforced AMCs, the matrix is the major load-bearing constituent. The role of the reinforcement is to strengthen and stiffen the composite by preventing matrix deformation by mechanical restraint.

In addition to four types of AMCs described above, another variant of AMCs known as hybrid AMCs have been developed and are in use to some extent. Hybrid AMCs essentially contain more than one type of reinforcement. For example, mixture of particle and whisker, or mixture of fiber and particle or mixture of hard and soft reinforcements. Aluminium matrix composite containing mixture of carbon fiber and alumina particles used in cylindrical liner applications is an example of hybrid composite. Figure 8d shows microstructure of hybrid AMC having both hard $\mathrm{SiC}$ and soft graphite particles as reinforcement [17].

Their advantages are low density, specific strength, high specific stiffness, high shear strength, low thermal expansion coefficient, thermal stability and thermal conductivity, good electrical conductivity, wear resistance and resistance to organic liquids and solvent erosion.
Moreover, the abundant aluminium resources in the world, coupled with conventional equipment and process processing and processing, and thus the preparation and production of aluminium-based composite materials than other metal-based composite materials more economical, easy to promote and apply. Therefore, the PAMCs in the economic field have a wide range of applications, and have been generally attached [27].

Granular aluminium composite materials used in the car, can reduce the weight of the car and improve its performance, and can save oil, reduce pollution and extend the service life. Compared with cast iron, with $\mathrm{A} 359+20 \%$ vo1. SiC brake discs, weight reduction of 50 to $60 \%$, such as $5.4 \mathrm{~kg}$ weight cast iron plate with a composite material instead of weighing only $2.5 \mathrm{~kg}$, after $5000 \mathrm{~km}$ travel test shows that the composite brake disc wear less, and can reduce the brake noise and improve the thermal conductivity (cast iron is 5 to 7 times) [27].

Knorr Bremse AG developed a high-speed train brake disc for the German ICE-2 high-speed rail with a weight loss of $500 \mathrm{~kg}$ per unit using $20 \% \mathrm{SiCp} / \mathrm{AlSi} 7 \mathrm{Mg}$ composites manufactured by Duralcan. Kolbenschmidt developed 20-30\% SiCp/Al-Si composite brakes for the Volkswagen Lupo - 3L TDI, similar brake discs for Toyota RAV - 4 EV cars, Plymouth prowler, Ford prodigy, Lotus Elise, etc. The Japan Toyota Motor Corporation manufactures $2 \mathrm{ZZ}$ - GE engine piston, piston ring, brake disc. Toyota Altezza has developed and produced TiB2/Ti composite exhaust valves [27] by powder metallurgy instead of 21-4 N steel. The high cost of particle reinforced aluminium-based composites limits its largescale production and application in the transportation sector.

In the paper [27] the research status of PAMCs preparation and forming technology in recent years is reviewed. Although the preparation and forming process of PAMCs still remain in the laboratory stage, with the continuous maturing of preparation and forming process, the reduction of preparation cost and the new process of new technology have been continuously developed to enhance the aluminium matrix composites will be its excellent characteristics in the automotive and aerospace, aerospace, military and other high-end areas play a greater role.

Primary processes for manufacturing of AMCs at industrial scale can be classified into two main groups (Fig. 9).

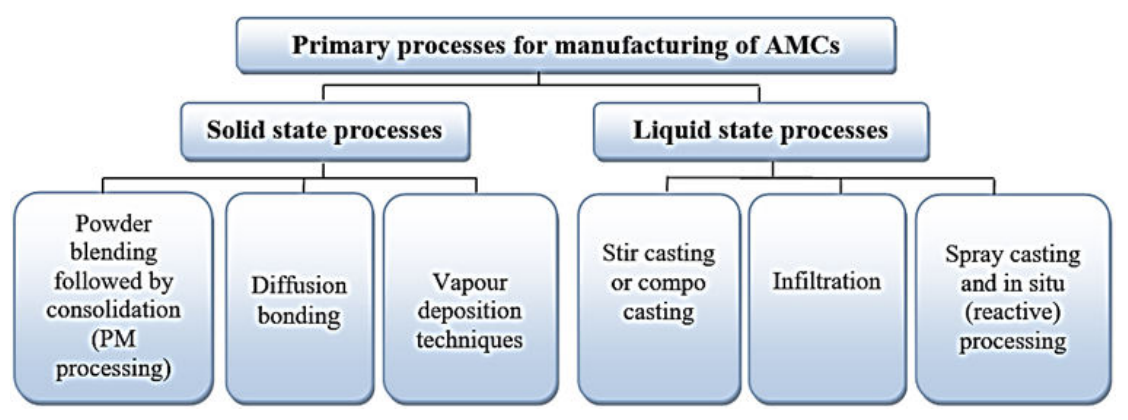

Figure 9 - Primary processes for manufacturing of AMCs 
The selection of the processing route depends on many factors including type and level of reinforcement loading and the degree of microstructural integrity desired. Table 2 provides feasibility of various primary processes for manufacturing different types of AMCs.
It is evident from the Table 2, that very often it is possible to manufacture AMC of specific formulation (having the same matrix and reinforcement combination) by more than one route [32].

Table 2- Primary processing routes of AMCs

\begin{tabular}{|c|c|c|c|c|}
\hline \multirow{2}{*}{$\begin{array}{c}\text { Primary processes } \\
\text { for manufacturing }\end{array}$} & CFAMCs & MFAMCs & PAMCs & SAMCs \\
\cline { 2 - 5 } $\begin{array}{c}\text { Blending and } \\
\text { consolidation }\end{array}$ & Not in practice & Not in practice & In use & In use \\
\hline $\begin{array}{c}\text { Diffusion } \\
\text { Bonding }\end{array}$ & Not in practice & In use & Not in practice & Not in practice \\
\hline $\begin{array}{c}\text { Vapour deposition } \\
\text { and consolidations }\end{array}$ & In use & In use & In use \\
\hline $\begin{array}{c}\text { Stir casting/slurs } \\
\text { casting }\end{array}$ & Not in practice & Not in practice & In use & Generally not use \\
\hline $\begin{array}{c}\text { Infiltration } \\
\text { process }\end{array}$ & In use & Generally not use & In use & In use \\
\hline $\begin{array}{c}\text { Spray deposition } \\
\text { and consolidation }\end{array}$ & Not in practice & In use & In use \\
\hline
\end{tabular}

\subsection{Modern polymer and composite materials}

The polymer composites in automotive applications today are glass fiber-reinforced thermoset polymers used mostly in non-structural parts of the vehicle especially for low- and mid-volume cars and trucks [33]. Fiberreinforced thermoplastics and, especially, carbon fiber reinforced thermosets show great potential, the latter having twice the weight reduction potential of glass fiberreinforced thermoset polymers. Fiber-reinforced thermoplastics share the advantageous properties of polymer matrix composites and are also recyclable, have indefinite shelf life, and feasible for automated, high volume processing with a potential for rapid and low cost fabrication. The cost is the single most major barrier for the limited application of polymer composites in automobiles today [11].For example, from carbon plastic were made such cars: Chevrolet Corvette, Audi R8 and Lamborghini Veneno.
About $80 \%$ of plastics used in automobiles consist in five types of materials: polyurethanes, polyvinylchlorides, polypropylenes, ABS plastics, fiberglass plastics. The remaining $20 \%$ are polyethylenes, polyamides, polyacrylates, and polycarbonates.

Under the fiberglass there is meant any fibrous filler that is impregnated with polymer resins. The most famous fillers are carbon fiber, glass fiber and kevlar. The outer panels of the bodies are made of fiberglass, which provides a significant reduction in the mass of the car (Fig. 10).

Pillows and seat backrests, shock-resistant pads made of polyurethane. A relatively new direction is the use of this material for the manufacture of wings, hoods, trunk lid. Polyvinylchloride is used for the manufacture of many fittings (shields, grips) and upholstery materials (fabrics, mats).From polypropylene make body of headlights, steering wheels, partitions and much more. ABS plastics are used for various facing details.

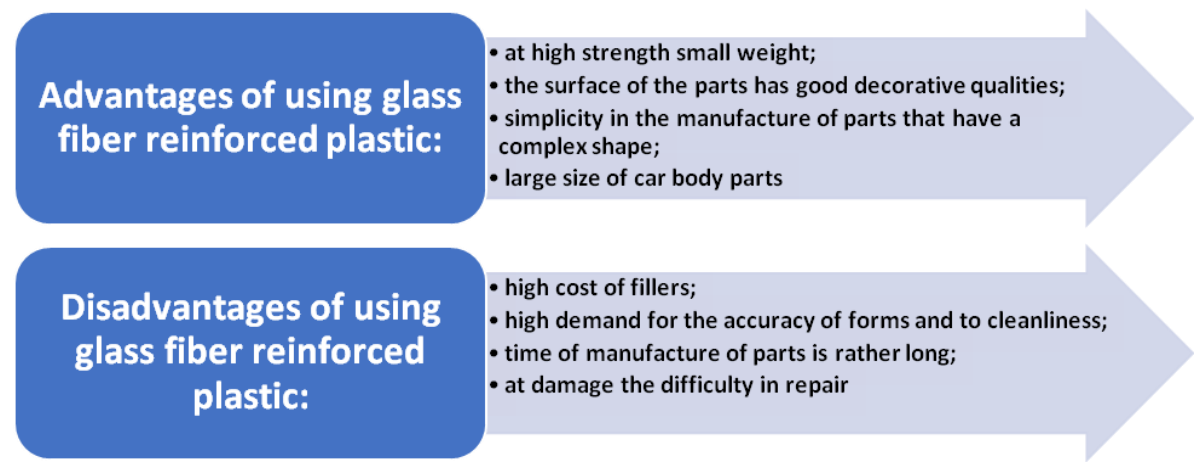

Figure 10 - Advantages and disadvantages of using glass fiber reinforced plastic for automotive industry 
The body of the new electric car BMW i3 is largely made of carbon fiber, which made it possible to increase the weight of the battery by $250-350 \mathrm{~kg}$. In fact, the body is made of synthetic material reinforced with carbon fiber. In the terminology of BMW, a new material is named Carbon Fiber Reinforced Plastic (CFRP). It is very durable and light but expensive composite material with fiberglass reinforced plastic. Some composites contain both carbon fibers and other fibers such as kevlar, aluminum and fiberglass reinforcement. Less commonly used materials such as graphite reinforced with fiberglass or miligraphite fibers reinforced with plastic (fiberglass). The car body of this material is $50 \%$ lighter than steel and $30 \%$ lighter than aluminium. Structural elements of the new material can be easily combined with aluminum body panels or metalized [34].

At the moment, carbon fiber is used for light sports models and for very expensive cars. The process of making car body and other models of carbon fiber plastics or with the content of carbon fiber takes a lot of time, and therefore this way is expensive. However, the study of this material allows you to improve the technology of manufacturing parts from it in the direction of reducing production time. This will allow you to arrange a serial release and lower the price accordingly.

Company ZF Friedrichshafen AG has developed a rear suspension for small class cars, where the elastic element is a transverse single-leaf springs made of synthetic material, but not carbon-fiber reinforced. The leaf spring is called the Transverse Composite Leaf Spring and also performs the function of the suspension guide. Such suspension can be applied also for electric cars. As is wellknown, McPherson's pendant has a widespread distribution, consisting of a single block, which includes a spring springs, and a shock absorber, and quite powerful binding and fixing elements.

Polymer materials, mostly made in the form of cast products, films and technical textiles, are highly valued in areas of modern economy in many thanks to their heat resistance, thermal resistance, mechanical strength, dimensional stability, and resistance to chemical reagents, fire and moisture resistance, low specific density and other consumer properties.

Along with this, the most important area is constructive details where long-fiber reinforced materials such as Vertron from GE Plastics Deutschland, with excellent shock properties and heat resistance, will be used. The similar characteristics are the long-fiber thermoplastic Celstran, which has found application in the external interface and in the door module of the Jaguar car.

Today, due to the usability of the equipment, polymers are required to be used even where they are more expensive. For example, the production of polycarbonate headlamps is 2.5 times more expensive than mineral glass; nevertheless, it leaves this automotive sector. New types of coatings and molding technologies of complex threedimensional parts made of polycarbonate make it possible to receive not only light but also extremely durable products. The economical two-component injection molding allows the use of polymers in the exterior of the car. Therefore, the consumer will soon be available lightweight panoramic roofs, luggage compartment covers with integrated locks and handles, etc.

The Swiss company EMS-Chemie has developed a polyphthalamide suitable for areas where metals need to be replaced. This polymer, used in the central gearbox switch, replaces ordinary aluminum. Such material is stable in size and wear, while maintaining high pressures and temperatures, with peak values well above $200{ }^{\circ} \mathrm{C}$. Long-lasting loads at temperatures up to $160{ }^{\circ} \mathrm{C}$ are possible. In comparison with aluminum structural elements, which require eight technological operations, a polyfetamide component can be made in two operations.

Auto experts predict that by 2040 half of all new cars that come down from the conveyor will be hybrid. However, in a hybrid car there is one problem: the battery whose energy is used to operate the electric motor is very cumbersome and difficult, even with the current development of lithium-ion batteries. In Europe, a group of nine automakers are currently testing body panels that can accumulate energy and charge faster than conventional batteries. They are made of polymer carbon fiber and resin; the batteries are sturdy but flexible. Thanks to the development of car weight may fall by $15 \%$ [35].

To the novelties you can add the following [35]:

1. Airless tires. The specific design of tires made of thermoplastic resin, allows you to maintain the weight of the car thanks to the curved spokes.

2. Smart lights. Researchers at the Carnegie Mellon University have developed a headlight system that combines the camera, projector, split-prism and processor, which surprisingly reduces the number of drops in the driver's field of vision; the camera detects drops, the processor determines their future location, the projector in turn "bypasses" particles, covering only what is behind them; with the whole process taking about $13 \mu \mathrm{s}$.

3. Hydrophobic windows. Properties to repel water implemented in the model KIA CADENZA 2014.

\section{Conclusions}

Thus, we can conclude that the automotive industry is not standing still and developing to the satisfaction of the consumer who wants a fast and safe car. At the expense of innovative development of automobile industry, it is possible to realize competitive products both on the national and international markets, which will ensure the country's entry into the international economic community. This leads to the fact that in the production of cars used increasingly new materials that meet modern requirements. 


\section{References}

1. Shashank, M. (2016). Material Qualification in the Automotive Industry. Center for Automotive Research. Ann Arbor, pp. 1-24.

2. Sharon, F. (2014). Additive Manufacturing Technology: Potential Implications for U.S. Manufacturing Competitiveness. Journal of International Commerce and Economics. Retrieved from http://www.usitc.gov/journals.

3. Materials-for-ground-transportation. Retrieved from https://www.britannica.com/technology/materials-science/Materials-forground-transportation.

4. Prokhorova, T. V., Perhemlyi, I. F., \& Kolesnikov, V. O. (2017). Materialy ta tekhnolohiyi v avtomobil'niy promyslovosti [Materialsand Technologies in theAutomotiveIndustry]. Materials of the V International Scientific and Technical Internet Conference "Problems and Prospects for the Development of Automobile Transport". Vinnytsya, Ukraine, pp. 105-112 [in Ukrainian].

5. What Materials are Used to Lightweight Cars? (2017). Trevor English, February 8, Blog, automotive, lightweighting, material. Retrieved from http://manufacturinglounge.com/materials-used-lightweight-cars.

6. Legkiye i prochnyyesinteticheskiyematerialy $\mathrm{v}$ avtomobilestroyenii [Lightweight and durable synthetic materials in the automotive industry]. Retrieved from http://1001s.ru/index.php/novosti/proizvodstvo/119-legkie-i-prochnye-sinteticheskie-materialy-vavtomobilestroenii [in Russian].

7. Monteiro, W. A., Buso, S. J., \& Silva, L. V. (2012). Application of Magnesium Alloys in Transport. New Features on Magnesium Alloys. Chapter 7. DOI: http://dx.doi.org/10.5772/48273.

8. Steel Applications. Retrieved from https://www.thebalance.com/steel-applications-2340171.

9. Kozlowski, M. (2012). Lightweight Plastic Materials. Thermoplastic Elastomers. Retrieved from http://www.intechopen.com/books/thermoplasticelastomers/lightweight-plastic-materials.

10. Mavhungua, S. T., Akinlabib, E. T., Onitirib, M. A., \& Varachiaa, F. M. (2017) Aluminum Matrix Composites for Industrial Use: Advances and Trends. Procedia Manufacturing, Vol. 7, 178-182. DOI: https://doi.org/10.1016/j.promfg.2016.12.045.

11. Das, S. (2000). The cost of automotive polymer composites: a review and assessment of doe's lightweight materials composites research - ORNL, TM-2000, pp. 283.

12. Top 5 Materials Used in Auto Manufacturing. Retrieved from https://auto.howstuffworks.com/under-the-hood/automanufacturing/5-materials-used-in-auto-manufacturing.

13. Iz chego delayut kuzova avtomobiley? Retrieved from http://amastercar.ru/articles/body_of_car_3.shtml [in Russian].

14. Kuzovnoye materialovedeniye [Body Material Science]. Retrieved from https://www.autocentre.ua/opyt/tehnologii/kuzovnoematerialovedenie-286800.html [in Russian].

15. Automotive steels for safe and lightweight cars. Retrieved from https://www.ssab.com/products/industries/automotive.

16. Ivanov, V. O., Karpus, V. Ye, Degtyarev, I. M., \& Bohdan, V. R. (2015). Tekhnolohiya vyhotovlennya avtomobil'nykh detaley skladnoyi formy [Technology of manufacture of automotive details of composite form]. Zbirnyk naukovykh prats' Natsional'noyi akademiyi Natsional'noyi hvardiyi Ukrayiny, No. 1 (25), 85-90.

17. Surappa, M. K. (2003). Aluminium matrix composites: Challenges and opportunities. SADHANA, Vol. 28, Parts 1-2, 319-334.

18. Mityaev, A. A., Volchok, I. P., et al. (2014). Kompleksnoe modyfytsyrovanye vtorychnykh sylumynov [Complex modification of secondary silumines]. Nauka ta prohrestransportu. Bulletin of Dnipropetrovsk national university of railway transport, Vol. 54, No. 6, 87-96. DOI: 10.15802/stp2014/33180) [in Russian].

19. Vakulenko, I. A., Nadezhdin, Y. L., et. al. (2013). Electric pulse treatment of welded joint of aluminium alloy. Nauka ta prohres transportu. Bulletin of Dnipropetrovsk national university of railway transport, Vol. 46, No. 4, 73-82. DOI: $10.15802 /$ stp2014/33180.

20. Pietrowski, S., Gumienny, G., Pisarek, B., \& Wladysiak, R. (2004). Kontrola produkcji wysokojakosciowych stopow odlewniczych metoda ATD -Archiwum technologii maszyn i automatyzacji, Vol. 24, No. 3, 131-144 [in Poland].

21. Volchok, I. P., \& Mitiaiev, O. A. (2003). Modyfikator dlia aliuminiievykh splaviv [Modifier for aluminium alloys]. Patent UA, No. 2002108343.

22. Volchok, I. P. Mitiaiev, O. A., Ostrovska, A. Ye., \& Skuibida, O. L. (2009). Modyfikator aliuminiievykh splaviv [Modifier of aluminium alloys]. Patent UA, No. u200902454.

23. Shyrokobokova, N. V., Mitiaiev, O. A., et al. (2012). Rafinuvalno-modyfikuvalnyi kompleks dlia aliuminiievykh splaviv [Refining and modifying complex for aluminium alloys]. Patent UA, No. u201112705.

24. Belikov, S., Volchok, I., \& Mityayev, O. (2006). The nanomodifier of aluminium alloys. Aims for future of engineering science, pp. 191-193.

25. Volochko, A. T. (2015). Modifitsirovaniye evtekticheskikh i pervichnykh chastits kremniya v siluminakh. Perspektivy razvitiya [Modification of eutectic and primary silicon particles in silumin. Prospects for development]. Casting and metallurgy, Vol. 81, No. 4, 38-45 [in Russian].

26. Telang, A. K., Rehman, A., Dixit, G., \& Das, S. (2010). Alternate materials in automobile brake disc applications with emphasis on Al composites - a technical review. Journal of Engineering Research and Studies, Vol. 1, Issue 1, 35-46. 
27. Tian, X., Zhu, A., Wei, J., \& Han, R. (2017). Preparation and Forming Technology of Particle Reinforced Aluminum Matrix Composites. Materials Science: Advanced Composite Materials, Vol. 1, Issue 1, 1-9.

28. Mironova, E. V., Zatulovsky, A. S., Kosinskaya, A. V., \& Zatulovsky, S. S. (2006). Lityye kompozitsionnyye materially na osnove alyuminiyevogo splava dlya avtomobilestroyeniya [Cast composite materials based on aluminium alloy for automotive industry]. Bulletin of Kharkov National Automobile and Highway University, No. 33, 20-22 [inRussian].

29. Kalinina, N. E., Beloyartseva, V. P., \& Kavats, O. A. (2006). Modifitsirovaniye liteynykh alyuminiyevykh splavov poroshkovymi kompozitsiyami [Modification of cast aluminum alloys by powder compositions]. Bulletin of Engine Building, No. 2, 193-195 [in Russian].

30. Stetsenko, V. Yu., Rivkin, A. I., Gutev, A. P., \& Konovalov, R. V. (2009). Modifitsirovaniye siluminom s melkokristallicheskimi alyuminiyevymi splavami [Modification of silumin with fine-crystalline aluminium alloys]. Bulletin of Gomel State Technical University named after P. O. Sukhoi, No. 1, 21-24 [inRussian].

31. Meenakshi, S. U. \& Mahamani, A. (2015). Development of Carbon Nanotube Reinforced Aluminum Matrix Composite Brake Drum for Automotive Applications. Research and Innovation in Carbon Nanotube-Based Composites. Retrieved fromhttp://www.academicpub.org/amsa.

32. Canter, N. (2016). Light weight self-lubricating metal matrix composites. Tribology \& Lubrication Technology, pp. 18-19.

33. Timoshkov, P. N., Khrulkov, A. V., \& Yazvenko, L. N. (2017). Kompozitsionnyye materialy v avtomobil'noy promyshlennosti [Composite materials in theautomotive industry]. Proceedings of VIAM, Vol. 54, No. 6, 61-68 [in Russian].

34. Gribkov, A. A. (2013). Novyye materialy, primenyayemyye v avtomobil'noy promyshlennosti [New materials used in the automotive industry]. Materials of the international scientific and practical conference "Innovations in the automotive industry", pp. 18-22 [in Russian].

35. 10 tekhnologiy avtomobiley budushchego [10 Future Car Technologies]. Retrieved from http://www.lookatme.ru/mag/live/ futureresearch/197165-future-car-technologies [in Russian]. 